\title{
Influence of storage temperature and duration on Mango fruit quality during post storage simulated marketing
}

\author{
Badshah Islam ${ }^{1 *}$ and Abdur Rab ${ }^{2}$ \\ 1. Department of Agriculture, Abdul Wali Khan University, Mardan, Pakistan \\ 2. Department of Horticulture, The University of Agriculture, Peshawar, Pakistan \\ *Corresponding author's email: badshahislam@gmail.com \\ Citation \\ Badshah Islam and Abdur Rab. Influence of storage temperature and duration on Mango fruit quality during post \\ storage simulated marketing. Pure and Applied Biology. Vol. 5, Issue 1, 2016, pp 91-101. \\ http://dx.doi.org/10.19045/bspab.2016.50012
}

Received: 08/10/2015

Revised: 09/12/2015

Accepted: 16/12/2015

Online First: 08/01/2016

\section{Abstract}

Present study investigated the influence of storage temperature $\left(5,10\right.$ and $\left.15 \pm 1{ }^{\circ} \mathrm{C}\right)$ and duration $(5,10,15,20,25$ and 30 days) on mango fruit quality during post storage. Physicochemical attributes of mango fruit were analyzed after 3 days post-storage simulated marketing. The experiment was laid out in a completely randomized design with three repeats. With the increase in pre-simulation storage duration, fruit juice $\mathrm{pH}$ and reducing sugars increased, while fruit firmness, titratable acidity and non-reducing sugars decreased during simulated marketing. The mean total soluble solids (TSS) initially increased and then declined as the pre-simulation time was prolonged. The fruits subjected to $10 \pm 1{ }^{\circ} \mathrm{C}$ maintained the highest mean TSS followed by $5 \pm 1{ }^{\circ} \mathrm{C}$, which was the least in fruits subjected to $15 \pm 1{ }^{\circ} \mathrm{C}$. Fruit firmness $\left(0.88 \mathrm{~kg} \mathrm{~cm}^{-2}\right)$, titratable acidity $(0.53 \%)$ and non-reducing sugars $(6.67 \%)$ were the highest in fruits exposed to $5 \pm 1^{\circ} \mathrm{C}$ before simulated marketing. Likewise, reducing sugars increased with the rise in storage temperature. The interaction revealed a steady increase in reducing sugars and slow decrease in non-reducing sugars of fruits exposed to $5 \pm 1{ }^{\circ} \mathrm{C}$, which indicates the slow conversion of carbohydrate polymers into monomers. The TSS continued to increase up to 25 days in fruits stored at $5 \pm 1{ }^{\circ} \mathrm{C}$ and on day 30 it declined whereas, such decline during simulated marketing, was observed after 5 and 15 days respectively in fruits stored at 15 and $10 \pm 1{ }^{\circ} \mathrm{C}$. Fruits stored at $5 \pm 1{ }^{\circ} \mathrm{C}$ maintained better quality attributes however, the incidence of chilling injury at $5 \pm 1{ }^{\circ} \mathrm{C}$ restricted mango storage at the same temperature. Therefore, if proper measures for the alleviation of chilling injury are not available, fruits of mango cv. "Langra" may be stored at 10 $\pm 1{ }^{\circ} \mathrm{C}$.

Key words: Mango; Storage; Simulated marketing; Temperature

\section{Introduction}

Pakistan is an agricultural country and production of fruits is the part and parcel of this sector. Mango (Mangifera indica L.) is the king of fruits and one of the most important fruit crops in the world as well as in Pakistan. It is a tropical [1], climacteric fruit liked by all due to its taste, flavor and excellent nutritional properties. High vitamin $\mathrm{A}$ and $\mathrm{C}$ contents, both being antioxidants help reduce risk of cancer and the process of aging. It is a delicious fruit and is 
grown in more than 87 countries of the world. Pakistani mango being superb in qualities is sold all over the world at good prices.

Pakistan stands fourth in the world mango export [2] with a share of $7.8 \%$ [3]. Pakistan exported 105.21 thousand tons of mangoes during 2006 [4]. Despite of producing top quality mangoes and lower cost of production e.g. Rs.59619.6 per acre [5], Pakistan could not tape on the full potential.

Mango fruit is processed to various products like jam, candy, mango drinks and canned slices. However, its consumption as fresh fruit is generally favored. As mango has a short production season therefore, proper storage technologies are required to ensure its availability in the market for longer time [6]. Mango is highly perishable and the quality of fruits stored at ambient temperature declines rapidly [7] due to higher rates of catabolic processes [8]. The physiological processes causing aging and senescence are reduced at low temperature [9-11]. Therefore, fruits and vegetables are generally stored in cold storage to extend their postharvest life [12, 13]. However, mango is a tropical fruit and low temperature storage may cause chilling injury [14] that increases the rates of respiration [15], ethylene synthesis [16] and electrolytes leakage [17] which in turn reduce the quality and acceptability of fruits [18].

The symptoms of chilling injury and its effects on fruit quality are sometimes visible at low temperature, but generally, become more prominent when fruits are shifted from cold storage to warmer temperature for marketing [19-21]. Keeping in view the high perishability of mango at ambient temperature and chilling sensitivity and the resulting fruit deterioration at low temperature, it is essential to optimize the storage temperature for quality retention. The present experiment was, therefore, designed to investigate the influence of storage temperature and duration on the physico-chemical changes in mango $\mathrm{cv}$. "Langra" fruits during simulated marketing after cold storage.

\section{Materials and Methods}

\section{Materials and experimental design}

The Mango fruits of cv. "Langra" were collected from Agricultural Extension Farm, Dera Ismail Khan during June, 2012. The fruits were picked at physiological maturity stage and stalks were removed with surgical blade. Fruits were shifted to the laboratory in corrugated cardboard boxed on the same day and washed with tape water. Fruits damaged during transportation were removed and physically sound fruits were selected. These fruits were allocated to different treatments and stored for 5, 10, 15, 20, 25 and 30 days (Factor A) at 5, 10 and $15 \pm 1{ }^{\circ} \mathrm{C}$ (Factor B). The experiment was laid out in completely randomized design with three repeats. Ten fruits were included in each treatment per repeat. After completion of the respective storage duration, these fruits were transferred to the simulated marketing condition for 3 days at mean temperature of $35 \pm 2{ }^{\circ} \mathrm{C}$. The fruits in each treatment on completion of 3 days simulated marketing were analyzed for fruit firmness, total soluble solids, titratable acidity, reducing sugars and non-reducing sugars.

\section{Methods of recording data}

Fruit firmness was determined by using a penetrometer (model, FT 327, Italy) with $8 \mathrm{~mm}$ plunger. After peeling, two readings were taken at the equatorial region on opposite sides on the flesh of each fruit and the average was calculated for each treatment [22].

For determination of total soluble solids the standard method of AOAC (2000) was used. The prism of a hand refractometer (model, RHB, 0-80 degree) was thoroughly washed twice with distilled water and dried with tissue paper. A drop of juice prepared from 
mango fruits of each treatment was placed on it. Three readings for each treatment were taken and then the average was recorded.

Titratable acidity of the selected mango juice was determined by standard method of AOAC (2000), by titrating against standard alkali solution and was expressed as citric acid percentage. Mango juice $(10 \mathrm{ml})$ was taken in a beaker, diluted with $100 \mathrm{ml}$ distilled water and two drops of phenolphthalein were added as indicator. Titration was carried out against $0.1 \mathrm{~N}$ Sodium hydroxide solution till the appearance of light pink color. The acidity was calculated by the following formula.

$$
\text { Acidity }(\%)=\frac{T \times \text { Acid factor } \times 100}{L \times M} \times 100
$$

$\mathrm{T}=\mathrm{ml}$ of $\mathrm{NaOH}$ used.

$\mathrm{L}=$ Sample taken $(\mathrm{ml})$ for dilution

$\mathrm{M}=\mathrm{ml}$ of diluted sample taken for titration

Reducing sugars were determined according to AOAC (2000) procedure explained as under.

Mango juice (10 g) was dissolved in $100 \mathrm{ml}$ distilled water and the burette was filled with it. $5 \mathrm{ml}$ Fehling $\mathrm{A}$ and $5 \mathrm{ml}$ Fehling B solution along with $10 \mathrm{ml}$ distilled water were taken in a conical flask. The flask was heated till boiling. The juice was added from the burette till the appearance of red brick color. A drop of methylene blue was used to check the persistency of red brick color. The titration continued till complete reduction of sugars. As $5 \mathrm{ml}$ of Fehling $\mathrm{A}$ and $5 \mathrm{ml}$ of Fehling $\mathrm{B}$ will reduce $0.05 \mathrm{~g}$ of reducing sugars so the calculations were carried out as under.

Reducing sugars $(\%)=\frac{0.05 \times \text { dilution } \times 100}{\text { Weightof sample } \times \text { titre }}$

For the determination of non-reducing sugars, a sample of $10 \mathrm{~g}$ was dissolved in
$100 \mathrm{ml}$ of distilled water. $20 \mathrm{ml}$ of this solution was taken in flask and $10 \mathrm{ml}$ of $1 \mathrm{~N}$ HCL was added to it. The flask was heated for 5-10 minutes and then $10 \mathrm{ml}$ of $1 \mathrm{~N}$ $\mathrm{NaOH}$ was added. The volume was made to $250 \mathrm{ml}$. This solution was taken in a burette and titrated against the boiling solution of 5 $\mathrm{ml}$ Fehling A and $5 \mathrm{ml}$ Fehling B solution taken in a flask with $10 \mathrm{ml}$ distilled water. The titration continued till the appearance of red color of which persistence was checked with a drop of methylene blue. In this way, total sugars were calculated. Non-reducing sugars were calculated as:

Non-reducing sugars $=$ Total sugars Reducing sugars

\section{Statistical analysis}

The data collected were subjected to Analysis of Variance (ANOVA) using Statistix 8.1 software [3]. Upon significant differences, the LSD (least significant difference) test was applied for the separation of mean values [23].

\section{Results and Discussion}

Fruit firmness $\left(\mathrm{kg} \mathrm{cm}^{-2}\right)$

Storage durations, storage temperatures and their interaction significantly affected the fruit firmness of mango during simulated marketing. A gradual decrease was observed in fruit firmness with the increase in storage duration. The highest fruit firmness $(1.22 \mathrm{~kg}$ $\mathrm{cm}^{-2}$ ) was recorded in fruits stored for 5 days followed by $0.83 \mathrm{~kg} \mathrm{~cm}^{-2}$ on day 10 , whereas, the least fruit firmness $(0.31 \mathrm{~kg}$ $\mathrm{cm}^{-2}$ ) was measured in fruits stored for 30 days (Table 1). The fruit firmness decreased with the increasing temperature. Fruits subjected to a pre-simulation storage at $5 \pm$ $1^{\circ} \mathrm{C}$ showed the maximum firmness $(0.88 \mathrm{~kg}$ $\left.\mathrm{cm}^{-2}\right)$ which was followed by $10 \pm 1^{\circ} \mathrm{C}(0.57$ $\mathrm{kg} \mathrm{cm} \mathrm{cm}^{-2}$ whereas, fruit firmness was minimum $\left(0.40 \mathrm{~kg} \mathrm{~cm}^{-2}\right)$ in fruits stored at $15 \pm 1^{\circ} \mathrm{C}$ before simulated marketing. The storage temperature and duration interaction revealed a significant decrease in firmness 
with the increase in both the storage temperature and duration. The highest fruit firmness $\left(1.60 \mathrm{~kg} \mathrm{~cm}^{-2}\right)$ during simulated marketing was recorded with storage at $5 \pm$ $1^{\circ} \mathrm{C}$ for 5 days and the least firmness $(0.19$ $\mathrm{kg} \mathrm{cm}^{-2}$ ) was measured at $15 \pm 1^{\circ} \mathrm{C}$ after 30 (Figure 1).

Table. Influence of storage durations and temperatures on mean fruit firmness (kg $\left.\mathrm{cm}^{-2}\right)$, TSS $\left({ }^{\circ}\right.$ Brix), titratable acidity $(\%)$, reducing sugars $(\%)$ and non-reducing sugars (\%) during simulated marketing after cold storage

\begin{tabular}{|c|c|c|c|c|c|}
\hline Treatments & $\begin{array}{l}\text { Fruit } \\
\text { firmness } \\
\left(\mathrm{kg} \mathrm{cm}^{-2}\right)\end{array}$ & $\begin{array}{l}\text { TSS } \\
\left({ }^{\circ} \text { Brix }\right)\end{array}$ & $\begin{array}{l}\text { Titratable } \\
\text { acidity } \\
(\%)\end{array}$ & $\begin{array}{l}\text { Reducing } \\
\text { sugars } \\
(\%)\end{array}$ & $\begin{array}{l}\text { Non- } \\
\text { reducing } \\
\text { sugars }(\%)\end{array}$ \\
\hline \multicolumn{6}{|c|}{ Temperature $\left(\mathrm{T}, \pm 1{ }^{\circ} \mathrm{C}\right)$} \\
\hline 5 & $0.88 \mathrm{a}$ & $19.97 \mathrm{a}$ & $0.53 \mathrm{a}$ & $4.87 \mathrm{c}$ & $6.67 \mathrm{a}$ \\
\hline 10 & $0.57 \mathrm{~b}$ & $20.06 \mathrm{a}$ & $0.40 \mathrm{~b}$ & $5.42 \mathrm{a}$ & $5.90 \mathrm{~b}$ \\
\hline 15 & $0.40 \mathrm{c}$ & $19.72 \mathrm{~b}$ & $0.35 \mathrm{c}$ & $5.33 \mathrm{~b}$ & $5.50 \mathrm{c}$ \\
\hline LSD at $\alpha=0.05$ & 0.08 & 0.21 & 0.026 & 0.07 & 0.16 \\
\hline \multicolumn{6}{|c|}{ Storage duration (SD, days) } \\
\hline $5+3$ & $1.22 \mathrm{a}$ & $19.44 \mathrm{~d}$ & $0.63 \mathrm{a}$ & $4.64 \mathrm{f}$ & $7.17 \mathrm{a}$ \\
\hline $10+3$ & $0.83 \mathrm{~b}$ & $20.33 \mathrm{~b}$ & $0.45 \mathrm{~b}$ & $4.91 \mathrm{e}$ & $6.77 \mathrm{~b}$ \\
\hline $15+3$ & $0.53 \mathrm{c}$ & $20.72 \mathrm{a}$ & $0.42 \mathrm{bc}$ & $5.11 \mathrm{~d}$ & $6.11 \mathrm{c}$ \\
\hline $20+3$ & $0.45 \mathrm{~cd}$ & $20.83 \mathrm{a}$ & $0.40 \mathrm{c}$ & $5.37 \mathrm{c}$ & $5.60 \mathrm{~d}$ \\
\hline $25+3$ & $0.37 \mathrm{de}$ & $19.78 \mathrm{c}$ & $0.33 \mathrm{~d}$ & $5.55 \mathrm{~b}$ & $5.40 \mathrm{~d}$ \\
\hline $30+3$ & $0.31 \mathrm{e}$ & $18.39 \mathrm{e}$ & $0.30 \mathrm{~d}$ & $5.66 \mathrm{a}$ & $5.08 \mathrm{e}$ \\
\hline LSD at $\alpha=0.05$ & 0.11 & 0.30 & 0.06 & 0.10 & 0.23 \\
\hline \multicolumn{6}{|l|}{ Interaction } \\
\hline $\mathrm{T} \times \mathrm{SD}$ & $*$ & $* *$ & $* *$ & $* *$ & $*$ \\
\hline
\end{tabular}

$* *=$ Significant at $\mathrm{p} \leq 0.01$

$*$ = Significant at $\mathrm{p} \leq 0.05$

In each category, means followed by different letter (s) are statistically different from each other at 5\% level of probability using LSD test.

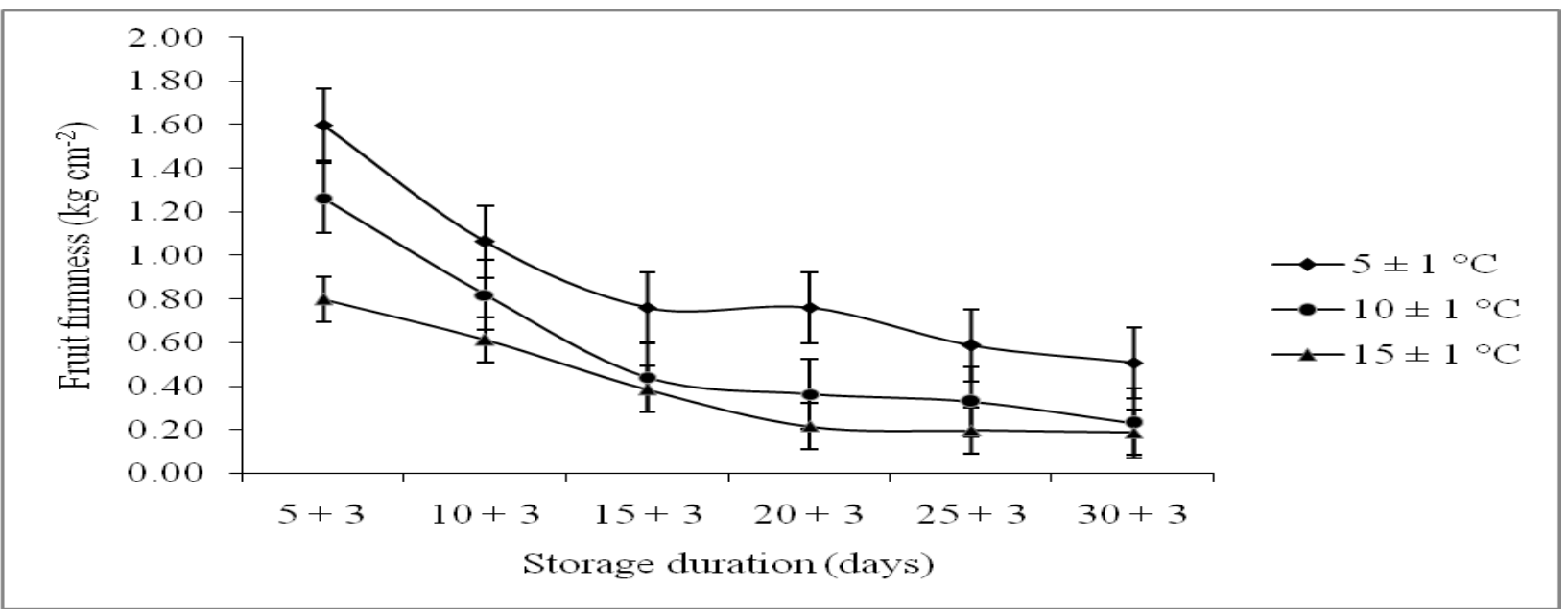

Figure 1. The interaction of storage duration and temperature for fruit firmness $\left(\mathrm{kg} \mathrm{cm}^{-2}\right)$. Vertical bars are standard errors of mean 
Increasing storage duration increased loss of fruit firmness due to the degradation of structural carbohydrates $[12,14,24,25]$. The fruit firmness decreased rapidly at higher temperature. Since, the firmness of fruits is maintained by the structural carbohydrates in the cell wall [26], higher enzymatic activities and ethylene production at higher temperature cause the hydrolysis of starch and pectic substances and increase the ripening process $[27,28]$. Thus, the fruits stored at low temperature $\left(5 \pm 1^{\circ} \mathrm{C}\right)$ retained the maximum firmness during simulated marketing.

\section{Total soluble solids ( ${ }^{\circ}$ Brix)}

The influence of storage durations, storage temperatures and their interaction on total soluble solids (TSS) was significant during simulated marketing. The TSS of fruits increased up to 20 days of storage and then declined. The TSS was maximum (20.83 ${ }^{\circ}$ Brix) in fruits stored for 20 days which was followed by $20.72{ }^{\circ}$ Brix at 15 days whereas, the lowest TSS (19.44 ${ }^{\circ}$ Brix) was measured in 5 days storage (Table 1). The mean for temperature revealed that TSS was the highest $\left(20.06{ }^{\circ}\right.$ Brix $)$ in fruits stored at $10 \pm$ $1^{\circ} \mathrm{C}$ which was statistically at par with 19.97 ${ }^{\circ}$ Brix of $5 \pm 1{ }^{\circ} \mathrm{C}$, whereas, the least TSS value $\left(19.72{ }^{\circ}\right.$ Brix) was recorded at $15 \pm$ $1^{\circ} \mathrm{C}$. The interaction of storage durations and temperatures showed that during simulated marketing, the TSS decreased after 5 days in fruits stored at $15 \pm 1^{\circ} \mathrm{C}$ and comparable decline was observed in fruits stored at $5 \pm$ $1^{\circ} \mathrm{C}$ after 30 days. A similar decline during simulated marketing was recorded after 20 days for fruit stored at $10 \pm 1{ }^{\circ} \mathrm{C}$. The maximum TSS (21.50 ${ }^{\circ}$ Brix $)$ during simulated marketing was measured in fruits stored for 25 days at $5 \pm 1^{\circ} \mathrm{C}$ whereas, the least was recorded in fruits stored for 30 days at $15 \pm 1^{\circ} \mathrm{C}$ (Figure 2 ).

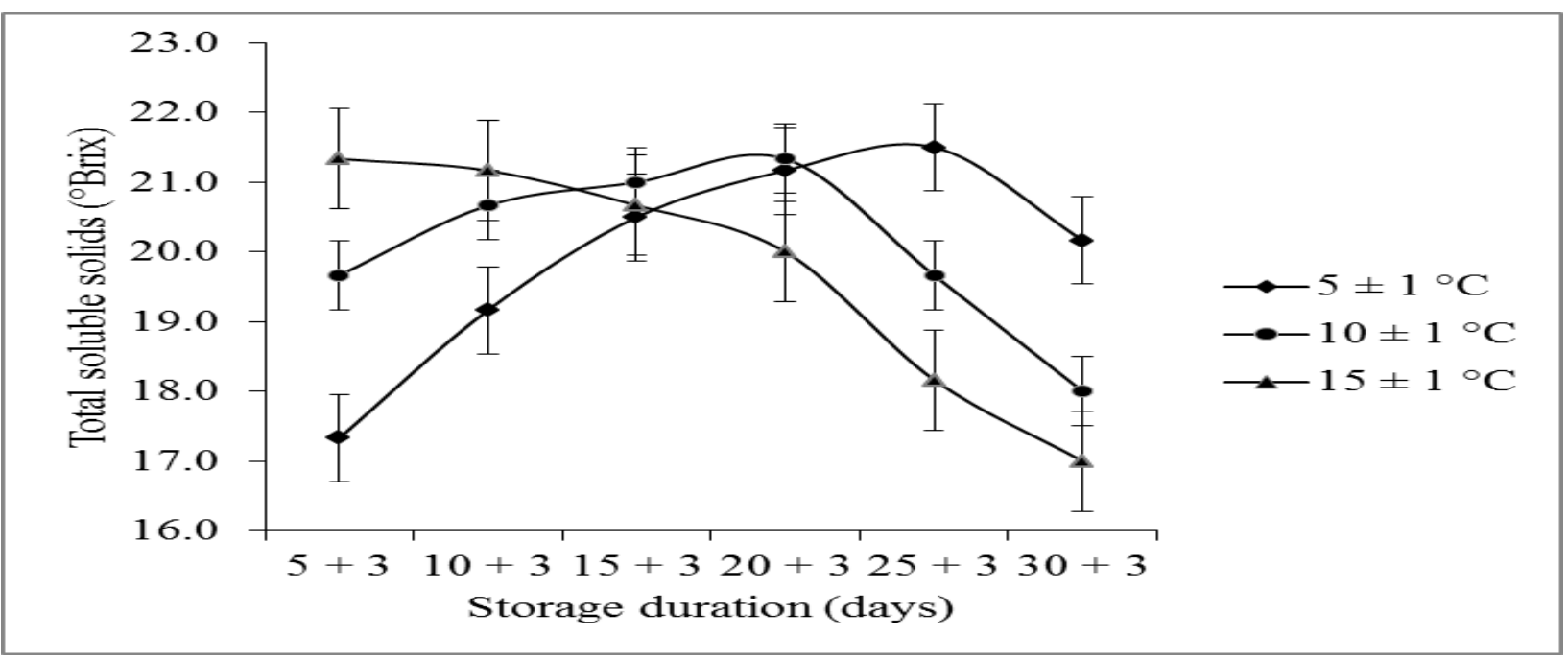

Figure 2. The interaction of storage duration and temperature for total soluble solids ( ${ }^{\circ}$ Brix). Vertical bars are standard errors of means.

The TSS increased initially with increasing storage duration but finally declined, which indicated the conversion of carbohydrate polymers into simpler form with the modest storage duration but the depletion of simple sugars through respiration when storage is extended beyond a critical duration $[8,29$ 31]. This may explain the least TSS with storage at $15 \pm 1^{\circ} \mathrm{C}$. The significantly lower total soluble solids content in fruits stored at 
$15 \pm 1^{\circ} \mathrm{C}$ after simulated marketing may be due to the rapid metabolism and a demand for respiratory substrate resulting in the conversion of starch into simple sugars [31]. The mean TSS was lower in fruits stored at $5 \pm 1^{\circ} \mathrm{C}$ before simulated marketing as compared to storage at $10 \pm 1{ }^{\circ} \mathrm{C}$ because low temperature reduces the conversion of starches to soluble sugars [31-33]. The effect of chilling injury may also be there that increases the rate of respiration especially after shifting to warmer marketing temperatures [34] and is evident in fruits stored for 30 days at $5 \pm 1^{\circ} \mathrm{C}$.

Titratable acidity (\%)

Storage durations, storage temperatures and their interaction significantly influenced the titratable acidity (Table 1) during simulated marketing. The acidity decreased with the increase in storage duration. The highest acidity $(0.63 \%)$ after simulated marketing was in fruits stored for 5 days followed by $0.45 \%$ at 10 days whereas, the lowest acidity $(0.30 \%)$ was in fruits stored for 30 days. The results revealed that acidity was inversely related to temperature. The low temperature favored the retention of acidity that was the maximum $(0.53 \%)$ at $5 \pm 1{ }^{\circ} \mathrm{C}$ while the lowest acidity (0.35\%) after simulated marketing was in fruits stored at $15 \pm 1{ }^{\circ} \mathrm{C}$. There is a negative relationship of titratable acidity with the storage temperature and durations. The acidity after simulated marketing was the maximum in fruits stored for 5 days at $5 \pm 1{ }^{\circ} \mathrm{C}$ and the minimum at 30 days on $15 \pm 1^{\circ} \mathrm{C}$ (Figure 3 ).

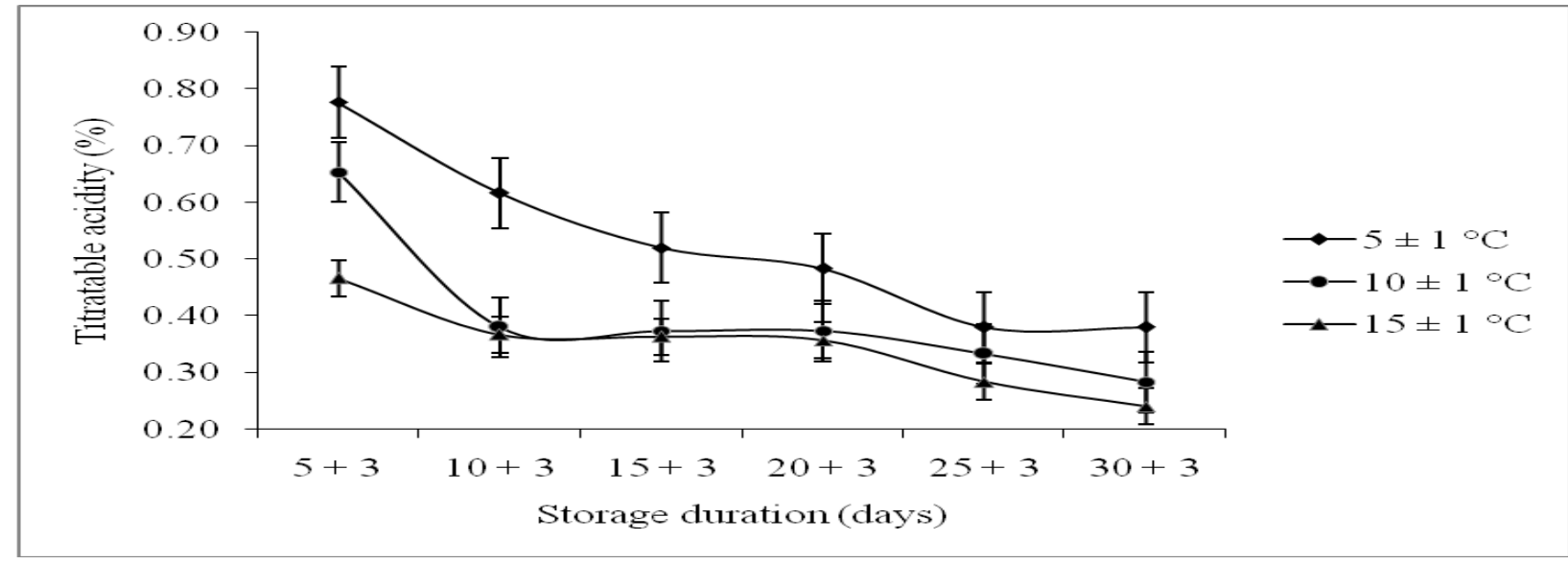

Figure 3. The interaction of storage duration and temperature for titratable acidity (\%).Vertical bars are standard errors of means.

The minimum titratable acidity after simulated marketing can be attributed to higher metabolic processes [33-35] in fruits stored at $15 \pm 1{ }^{\circ} \mathrm{C}$. However, the highest net decrease in acidity on shifting the fruits to simulated marketing, was in fruits stored at $5 \pm 1{ }^{\circ} \mathrm{C}$ (storage data not shown) which could be due to the abrupt rise in metabolism after removal from low temperature and accelerated conversion of citric acid to glucose or its use for energy during respiration [25]. It resulted in the maximum total decrease in acidity $(71.50 \%)$ at $5 \pm 1{ }^{\circ} \mathrm{C}$ as compared to 69.23 and $63.91 \%$ respectively for 10 and $15 \pm 1{ }^{\circ} \mathrm{C}$ during simulated marketing. Citric acid like other organic acids decreased with the increase in storage due to the increasing ripening [36-39]. The continuous decline in acidity with the extended storage in mango [25] is generally higher at higher temperature but is also triggered by low 
temperature on shifting to warmer marketing environment $[7,20,29]$.

\section{Reducing sugars (\%)}

The reducing sugars during simulated marketing were significantly influenced by pre-simulation storage durations, storage temperatures and their interaction. The reducing sugars during simulated marketing increased with the increasing storage duration with the highest reducing sugars $(5.66 \%)$ in fruits stored for 30 days whereas, the least $(4.65 \%)$ were for 5 days storage. Similarly, the highest reducing sugars content $(5.93 \%)$ was recorded in fruits stored at $10 \pm 1{ }^{\circ} \mathrm{C}$ followed by $5.33 \%$ at 15 $\pm 1{ }^{\circ} \mathrm{C}$ while it was the least $(4.90 \%)$ at $5 \pm 1$ ${ }^{\circ} \mathrm{C}$. The interaction of storage durations and temperatures also showed that reducing sugars increased during simulated marketing with the increase in storage temperature and storage duration. While the reducing sugars were the highest in fruits stored before simulation at $15 \pm 1{ }^{\circ} \mathrm{C}$ but more rapidly increased in fruits stored at $5 \pm 1{ }^{\circ} \mathrm{C}$ when shifted to simulated marketing conditions where the reducing sugars ranged from 4.23 to $5.54 \%$ (Figure 4 ).

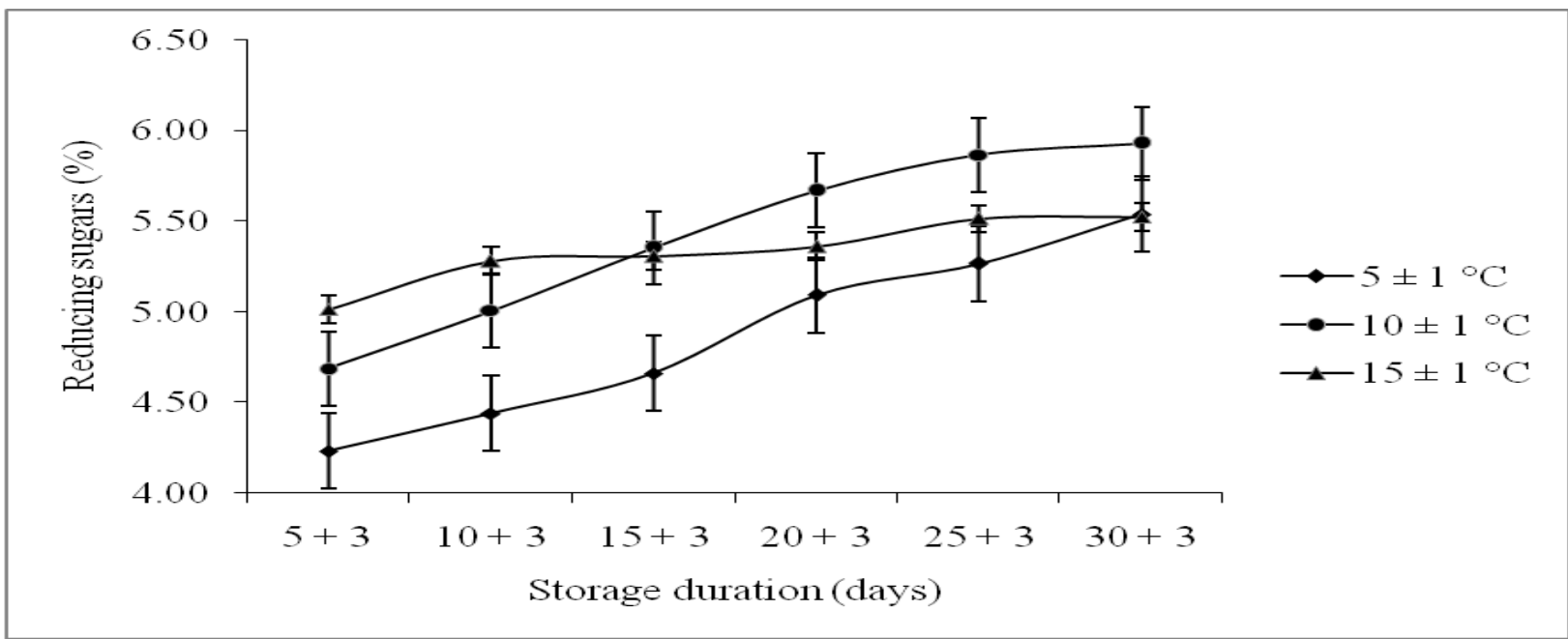

Figure 4. The interaction of temperature and storage duration for reducing sugars (\%).Vertical bars are standard errors of means.

After simulated marketing minimum reducing sugars in fruits stored at $5 \pm 1{ }^{\circ} \mathrm{C}$ is due to the slow conversion of structural carbohydrates, starch and non-reducing sugars to glucose and fructose $[12,29]$ during storage. The reducing sugars are used as substrate in respiration however, the conversion of oligosaccharides and polysaccharides was faster which resulted in the increased reducing sugars with the passage of time $[9,40,41]$. The low rate of increase in reducing sugars at $15 \pm 1^{\circ} \mathrm{C}$ may be because of the higher rate of respiration where most of the sugars are used as substrate for energy synthesis $[12,31]$. The rapid rate of increase in reducing sugars at 10 and $5 \pm 1{ }^{\circ} \mathrm{C}$ compared to $15 \pm 1{ }^{\circ} \mathrm{C}$ specifically after 15 and 20 days of storage is because of the abrupt increase in conversion of polysaccharides in to monosaccharide in fruits stored at lower temperatures [11].

\section{Non-reducing sugars (\%)}

The influence of storage durations, storage temperatures and their interaction on nonreducing sugars after simulated marketing was significant. The non-reducing sugars were negatively related with the storage duration which were maximum $(7.17 \%)$ in fruits stored for 5 days and declined to the 
minimum $(5.08 \%)$ in 30 days (Table). The lower storage temperature $\left(5 \pm 1{ }^{\circ} \mathrm{C}\right)$ retained the highest non-reducing sugars $(6.67 \%)$ after simulated marketing, whereas, the least $(5.50 \%)$ were in fruit stored at $15 \pm$ $1{ }^{\circ} \mathrm{C}$. The interaction of storage durations and temperatures depicted that non-reducing sugars decreased with the increase in both storage temperature and duration and the rate of decrease was the least at $5 \pm 1{ }^{\circ} \mathrm{C}$ (Figure 5).

The metabolic activities including the hydrolysis of non-reducing sugars generally increase with the extension in storage duration [41, 44], thus, a decrease was observed in non-reducing sugars with the increasing storage time. The higher nonreducing sugars in case of storage at low temperature and after simulated marketing indicated that reduced storage temperature delayed the conversion of these sugars into reducing sugars $[12,42,45]$. Since both the storage temperature and duration favored the decrease in non-reducing sugars, thus, the minimum non-reducing sugars with the maximum storage duration (30 days) and temperature $\left(15 \pm 1^{\circ} \mathrm{C}\right)$ were expected.

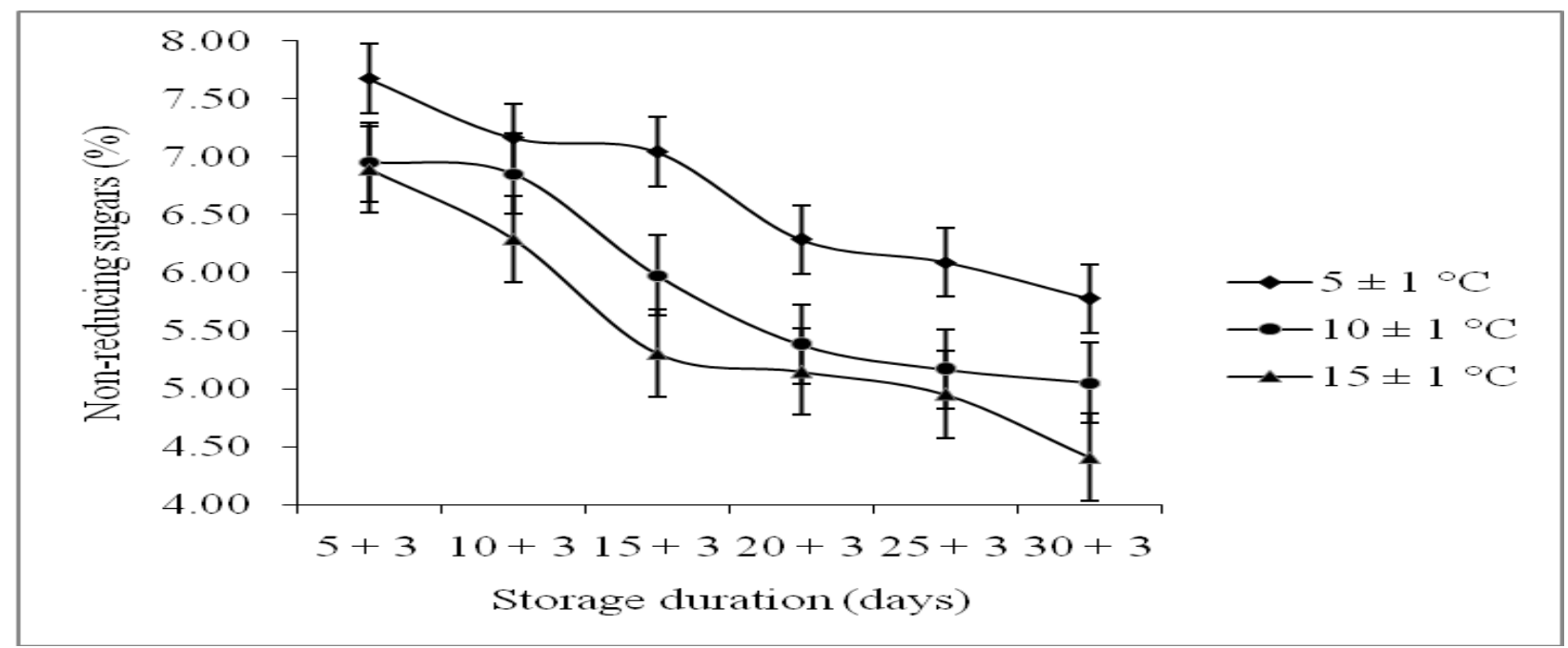

Figure 5. The interaction of temperature and storage duration for non-reducing sugars (\%).Vertical bars are standard errors of means.

\section{Conclusion}

Fruits stored at $5 \pm 1^{\circ} \mathrm{C}$ retained the highest firmness, titratable acidity and non-reducing sugars during simulated marketing that were followed by $10 \pm 1^{\circ} \mathrm{C}$ and all these attributes decreased with increasing the pre-simulation storage duration. TSS and reducing sugars were the highest in fruits stored at $10 \pm 1^{\circ} \mathrm{C}$ before simulated marketing followed by $5 \pm$ $1^{\circ} \mathrm{C}$ and were the least at $15 \pm 1^{\circ} \mathrm{C}$. The TSS increased up to 25 days and then declined whereas, reducing sugars increased when storage duration was prolonged.

\section{Authors' contributions}

Conceived and designed the experiments: A Rab \& B Islam, Performed the experiments: B Islam, Analyzed the data: A Rab, Wrote the paper: A Rab \& B Islam.

\section{Acknowledgement}

I am thankful to the Agricultural Officer, Department of Agriculture Extension, D.I. Khan for provision of fruit samples from mango groves of the said department and the authorities of Abdul Wali Khan University, Mardan for sponsoring this research work. 


\section{References}

1. Bakhsh K, Sleem BA, Malik AU \& Ziaf K (2005). Economics of mango growing in Punjab. International conference of mango and date palm. 20-23.

2. Maqbool M, Malik AU \& Jabbar A (2007). Sap dynamics and its management in commercial mango cultivars of Pakistan. Pak J Bot 39: 15651574.

3. Sauco VG (2004). Mango production and world market: Current situation and future prospects. Acta Hort 1: 107-116.

4. MINFA (2007). Agriculture Statistics of Pakistan. Govt. of Pakistan, Ministry of Food and Agriculture, Economic Wing, Islamabad.

5. Bakhsh K, Sleem BA, Malik AU \& Ziaf K (2005). Economics of mango growing in Punjab. International conference of mango and date palm. 20-23 June, 2005.

6. Pesis E, Aharoni D, Aharon Z, Ben-Arie R, Aharoni N \& Fuchs Y (2000). Modified atmosphere and modified humidity packaging alleviates chilling injury symptoms in mango fruit. Postharvest Biol Tec 19: 93-101.

7. Lelievre JM, Tichit L, Fillion L, Larrigaudiere C, Vendrell M \& Pech JC (1995). Cold-induced accumulation of 1aminocyclopropane 1-carboxylate oxidase protein in Granny Smith apples. Postharvest Biol Tec 5: 11-17.

8. Abbasi NA, Iqbal ZM, Maqbool M \& Hafiz IA (2009). Postharvest quality of mango (Mangifera indica L.) fruit as affected by chitosan coating. Pak J Bot 41: 343-357.

9. Rab A, Sajid M, Khan NU, Nawab K, Arif M \& Khattak MK (2012). Influence of storage temperature on fungal prevalence and quality of citrus fruit (cv. Blood red). Pak J Bot 44(2): 831-836.

10. Seyoum TW \& Woldetsadik K (2004). Forced ventilation evaporative cooling of fruits: A case study on Banana,
Papaya, Orange, Lemon and Mandarin. Trop Agric J 81(3): 179-185.

11. Tefera A, Seyoum $\mathrm{T} \&$ Woldetsadik K (2008). Effects of disinfection, packaging and evaporatively cooled storage on sugar content of mango. Afr J Biotecnol 7(1): 65-72.

12. Ahmad S, Thompson AK, Hafiz IA \& Asi AA (2001). Effect of temperature on the ripening behavior and quality of banana fruit. Int J Agr Biol 3(2): 224227.

13. Smith N (1989). Textural biochemical changes during ripening of banana. Ph.D. Thesis, University of Nottingham, UK.

14. Medlicott AP, Sigrist JMM \& Sy O (1990). Ripening of mango following low-temperature storage. $J \mathrm{Am}$ Soc Hortic Sci 115(3): 430-434.

15. Burns JK (1990). Respiratory rates and glycosidase activities of juice vesicles associated with section-drying in citrus. Hort Sci 25: 544-546.

16. Wen Q, Ma R, Dong Q \& Xin Y (2006). Studies on postharvest physiology and the storage technology of mango (Mangifera indica L.). J Food Process Preser 30: 670-683.

17. Fuchs Y, Zauberman G, Rot I \& Weksler A (1989). Chilling injury and electrolyte leakage in cold stored mango and avocado fruits. Acta Hort 258: 303308.

18. Mohammed $M$ \& Barthwaite RA (2000). Ripening effects on the chilling sensitivity of processing and nonprocessing tomato cultivars. J Appl Hort 2: 76-78.

19. Magness JR \& Taylor CF (1925). An improved type of pressure tester for the determination of fruit maturity. U.S. Dept. Agric. Circ. 350: 8.

20. Saltveit ME \& Morris LL (1990). Overview on chilling injury of horticultural crops. In: Wang, C.Y. 
(Ed.), Chilling Injury of Horticultural Crops. CRC Press, Boca Raton, FL, 313.

21. Serrano M, MartinezMadrid MC, Martinez G, Riquelme FMT, Pretel, \& Romojaro F (1996). Review: Role of polyamines in chilling injury of fruit and vegetables. Food Sci Tec Int 2:195199.

22. Magness JR \& Taylor CF (1925). An improved type of pressure tester for the determination of fruit maturity. U.S. Dept. Agric. Circ. No. 350: 8.

23. Steel RG \& Torrie JH (1980). Principles and procedures of statistics: A biometrical approach. 2nd Ed.McGrawHill Book Co., New York, NY.

24. Doreyappa-Gowda IND \& Huddar AG (2001). Studies on ripening changes in mango (Mangifera indica L.) fruits. $J$ Food Sci Tech 38: 135-137.

25. Gonzalez-Aguilar GA, Fortiz J, Cruz R, Baez R \& Wang CY (2000). Methyl jasmonate reduces chilling injury and maintains postharvest quality of mango fruit. J. Agric Food Chem 48: 515-519.

26. Manganaris GA, Vicente AR, Crisosto CH \& Labavitch JM (2008). Cell wall modifications in chilling-injured plum fruit (Prunus salicina). Postharvest Biol Tec 48: 77-83.

27. Gorny JR, Hess-Pierce B \& Kader AA (1998). Effect of fruit ripeness and storage temperature on the deterioration rate of fresh-cut peach and nectarine slices. Hort Sci 33(1): 110-113.

28. Kader A, \& Mitcham B (2008). Optimum procedures for ripening mangoes. Fruit Ripening and Ethylene Management: 47-48. Univ. Calif. Postharvest Technology Research and Information Center Publication.

29. Ezz TM \& Awad RM (2011). Effect of some post-harvest treatments under different low temperature on two mango cultivars. Austr J Basic Appl Sci 5(10): 1164-1174.

30. Rathore HA, Masud T, Sammi S \& Soomro AH (2007). Effect of storage on physico-chemical composition and sensory properties of Mango (Mangifera indica L.) variety Dosehari. Pakistan J Nutr 6: 143-148

31. Wen Q, Ma R, Dong Q \& Xin Y (2006). Studies on postharvest physiology and the storage technology of mango (Mangifera indica L.). J Food Process Preser 30: 670-683.

32. Medlicott A, Bhogol M \& Reynolds S (1986). Changes in peel pigmentation during ripening of mango fruit (Mangifera indica, var. Tommy Atkin). The Ann Appl Biol 109: 651-656.

33. Seyoum TW (2002). The improvement of the shelf life of vegetables through pre and postharvest treatment. Ph.D. Dissertation, University of Free State. South Africa.

34. Youssef BM, Asker AA, El-Samahy SK \& Swailam HM (2012). Combined effect of steaming and gamma irradiation on the quality of mango pulp stored at refrigerated temperature. Food Res Int 35(1): 1-13.

35. Tembo L, Chiteka ZA, Kadzere I, Akinnifesi FK \& Tagwira F (2008). Storage temperature affects fruit quality attributes of Ber (Ziziphus mauritiana Lamk.) in Zimbabwe. Afr J Biotecnol 7(8): 3092-3099.

36. Chandra R, Goving S \& Basuchaudhun P (1994). Pre-harvest sprays of calcium nitrate and Alar on quality and postharvest behaviour of guava fruits. Indian J Hill Farm 7(1): 51- 56.

37. El-Ghaouth A, Arul J, Ponnampalam R \& Boulet M (1991). Chitosan coating effect on storability and quality of fresh strawberries. J Food Sci 56: 1618-31.

38. Garcia MA, Martino MN \& Zaritzky NE (1998). Plasticized starch-based 
coatings to improve strawberry quality and stability. J Agric Food Chem 46: 3758-3767.

39. Jitareerat $P, \quad$ Paumchai $S \quad \&$ Kanlayanarat S (2007). Effect of chitosan on ripening enzymatic activity, and disease development in mango (Mangifera indica L.) fruit. New Zeal J Crop Hort Sci 35: 211-218.

40. Nilprapruck P, Pradisthakarn N, Authanithee F \& Keebjan P (2008). Effect of exogenous methyl jasmonate on chilling injury and quality of pineapple (Ananas comosus L.) cv. Pattavia. Silpakorn U Sci Tech J 2(2): 33-42.

41. Sajid M, Rab A, Jan I, Haq I, Shah ST, Iqbal A, Zamin M \& Shakur M (2012). Pre-harvest treatment of $\mathrm{Zn} \mathrm{\&} \mathrm{B} \mathrm{affects}$ the fruit quality and storability of sweet orange. J Agri Sci Technol 2: 12241233.
42. Arjona HE, Frank B, Matta, James O \& Garner Jr (1992). Temperature and storage time affect quality of yellow passion fruit. Hortic Sci 27(7): 809-810.

43. Rab A, Sajid M, Saeeda \& Najia. (2011). Effects of wet heat treatment (WHT) durations on the quality of sweet orange stored at room temperature. Sarhad J Agric 27 (2): 189-194.

44. Tadesse T, Workneh TS \& Woldetsadik K (2012). Effect of varieties on changes in sugar content and marketability of tomato stored under ambient conditions. Afr J Agri Res 7(14): 2124-2130.

45. Campbell CA, Huber DH, \& Koch KE (1989). Postharvest changes in sugars, acids, and color of carambola fruit at various temperatures. Hortic Sci 24: 472-475. 